\title{
Roda de Conversa como Estratégia de Apoio À Gestão.
}

\author{
Kleina, Sirlei Corssetti; Falavinha, Elisabeth D. Altimar \\ Hospital de Clinicas da UFPR — sirleick@yahoo.com.br
}

Neste estudo, pretendeu-se relatar a experiência das Rodas de Conversa realizadas em um Hospital Universitário da cidade de Curitiba e apresentar a análise dos resultados. a Política Nacional de Humanização (PNH) tem como Diretriz a Cogestão que trabalha os relacionamentos e os reconhecimentos necessários para o diálogo e a construção coletiva na buscando da qualidade nos serviços de saúde. Roda de Conversa $(\mathrm{RC})$ é estratégia de gestão da PNH, utilizada como método que abre espaço para escuta, diálogo e reflexões, permitindo a criação de novas estratégias a partir da experiência dos profissionais. Os desafios da gestão nas instituições de saúde vão além das questões gerenciais ou técnicas, temos uma questão de relacionamentos entre categorias, serviços e instituições que interferem e determinam os entraves e possíveis soluções na qualidade do Serviço. o reconhecimento destas interferências externas e entre as atividades dos profissionais, demanda uma mudança de atitude. uma proposta considerada de difícil solução que precisa de investimento em espaços de escuta e diálogos adequados, um desafio a ser enfrentado pelos profissionais das diversas áreas da saúde. Outro fator importante que também interfere neste processo é o imediatismo das equipes em solucionar as questões técnicas, de processos e relacionamentos; a dificuldade de participação; a impossibilidade de intervenção de trabalhadores e chefias em situações fora de sua governabilidade; e a limitação de falar dos problemas reais. Cabe aos profissionais da saúde iniciar a quebra destes paradigmas. o objetivo desta proposta é trabalhar a Cultura Institucional, buscar a mudança de atitude e desenvolver as equipes e gestores para a o modelo de gestão participava que visa o consenso e a construção coletiva. o método resulta em melhoria de fluxos e processos, otimização de recursos, corresponsabilização, motivação das equipes e fortalecimento da gestão, todos estes fatores refletem positivamente e transversalmente no atendimento da Instituição. Concluímos que este modelo de gestão apoiado pelo método da Roda de Conversa possibilita encontrar soluções efetivas para as demandas técnicas, a partir da reconstrução do relacionamento entre os vários atores envolvidos no processo.

Kleina, Sirlei Corssetti; Falavinha, Elisabeth D. Altimar. Roda de Conversa como Estratégia de Apoio À Gestão.. In: Anais do Congresso Internacional de Humanidades \& Humanização em Saúde [= Blucher Medical Proceedings, num.2, vol.1]. São Paulo: Editora Blucher, 2014. ISSN 2357-7282

DOI 10.5151/medpro-cihhs-10638 